\title{
Gray Mold Severity and Vase Life of Rose Buds after Pulsing with Citric Acid, Salicylic Acid, Calcium Sulfate, Sucrose and Silver Thiosulfate
}

\author{
Guy de Capdeville ${ }^{1}$, Luiz A. Maffia ${ }^{2 *}$, Fernando L. Finger ${ }^{3}$ \& Ulisses G. Batista ${ }^{2}$ \\ 'Embrapa Recursos Genéticos e Biotecnologia, CEP 70770-900 Brasília, DF, Tel.: +11 5561 4484707; Fax: +11 55613403658 , \\ e-mail: guy @ cenargen.embrapa.br; ${ }^{2}$ Departamentos de Fitopatologia; ${ }^{3}$ Fitotecnia, Universidade Federal de Viçosa, \\ CEP 36570-000 Viçosa, MG
}

(Accepted for publication on 16/04/2003)

Corresponding author. Guy de Capdeville

CAPDEVILLE, G. de, MAFFIA, L.A., FINGER, F.L. \& BATISTA, U.G. Gray mold severity and vase life of rose buds after pulsing with citric acid, salicylic acid, calcium sulfate, sucrose and silver thiosulfate. Fitopatologia Brasileira 28:380-385. 2003.

\begin{abstract}
Gray mold of roses (Rosa hibrida) caused by Botrytis cinerea requires many management strategies for its control. The effect of pulsing rose cv. Kiss with solutions of citric acid, salicylic acid, sucrose, calcium sulfate, and silver thiosulfate (STS) on disease severity and vase life of the flowers was evaluated. The solutions were applied to cut stems at different stages of harvest, the variation in the opening stage of harvest did not affect the results. Pulsing with STS reduced the values of area under the disease progress curve (AUDPC) and of

severity of disease by $15 \%$ and $55 \%$, respectively, and increased the vase life of the flowers by $20 \%$. Calcium sulfate consistently reduced AUDPC by $66 \%$ and maximum severity by $88 \%$, and increased vase life of the flowers by $37 \%$. Therefore, pulsing rose buds with solutions of STS and calcium sulfate is potentially useful in reducing losses due to gray mold after harvest and in extending the vase life.

Additional keywords: cut flowers, Rosa hybrida, Botrytis, Calcium, Silver thiosulfate, Postharvest.

\section{RESUMO}

Severidade do mofo cinzento e vida de vaso de botões de rosa após o pulsing com ácido cítrico, ácido salicílico, sulfato de cálcio, sacarose e tiossulfato de prata

O mofo cinzento das roseiras (Rosa hybrida), causado por Botrytis cinerea, requer muitas estratégias de manejo para seu controle. Botões de rosa (cv Kiss) foram submetidos ao pulsing com soluções de ácido cítrico, ácido salicílico, sulfato de cálcio, sacarose ou tiossulfato de prata (STS), para avaliar o efeito destes tratamentos sobre a severidade do mofo cinzento e a vida de vaso das flores. As soluções foram aplicadas a hastes colhidas em diferentes tempos em

relação ao ponto de colheita, mas a variação no ponto de colheita não produziu efeitos significativos. O tratamento com STS reduziu os valores de área abaixo da curva de progresso da doença (AACPD) e de severidade máxima em $15 \%$ e $55 \%$, respectivamente, e aumentou a vida de vaso das flores em $20 \%$. O sulfato de cálcio reduziu consistentemente a AACPD em $66 \%$ e a severidade máxima em $88 \%$, além de aumentar a vida de vaso em $37 \%$. Portanto, o pulsing de botões de rosa com soluções de STS e sulfato de cálcio é um tratamento potencialmente útil para reduzir as perdas devidas ao mofo cinzento e para aumentar a vida de vaso das flores.
\end{abstract}

\section{INTRODUCTION}

Rose (Rosa hybrida L.) flowers are subjected, after harvest, to a number of stress conditions that stimulate the production of ethylene. This hormone, even in concentrations as low as $0.06 \mu \mathrm{l} / \mathrm{l}^{-1}$, predisposes flowers to infection by Botrytis cinerea Pers. Fr. (Jarvis, 1977).

Pulsing flowers with substances such as citric acid, salicylic acid, sucrose, calcium sulfate, and silver thiosulfate (STS) is promising in reducing damage caused by $B$. cinerea (Nowak \& Rudnick, 1990; Torre et al., 1999). The term pulsing has been used by scientists to describe a technique where flower stems are immersed in a chemical solution to carry to the tissues, through the xylem, substances that may reduce senescence and increase the vase life of the flowers.

Citric acid seems to act by reducing the $\mathrm{pH}$ of water and, consequently, the proliferation of bacteria, which block the xylem vessels in the cut region and interfere with the normal flux of water through the stem (Nowak \& Rudnicki, 1990). There is little research on the effects of citric acid on the severity of gray mold in harvested roses or other species.

Salicylic acid has been tested for control of post harvest diseases. Gaur \& Chenulu (1982) determined that salicylic acid in concentrations of 100,500 , and $1000 \mu 1 / 1^{-1}$ was effective in controlling at least four pathogens of orange [Citrus sinensis (L.) Osbeck] and potato (Solanum tuberosum L.). Most of the research using salicylic acid is directed to induction of systemic acquired resistance (SAR) in hosts against the attack of pathogens (Ryals et al., 1996; De et al., 1999).

Sucrose has been used to increase the longevity of many kinds of flowers (Halevy et al., 1978a). Apparently, this sugar provides energy for fundamental cellular processes, such 
Gray mold severity and vase life of rose buds after...

as maintenance of the structure and function of mitochondria and other organelles. Sucrose also helps in the regulation of the flux of water and minerals into the xylem vessels by controlling transpiration (Nowak \& Rudnicki, 1990). It is important to emphasize the scarcity of research using sugars, in association or not with other substances, to control diseases.

Calcium ions in the form of sulfate $\left(\mathrm{CaSO}_{4}\right)$, chlorate $\left(\mathrm{CaCl}_{2}\right)$, or nitrate $\left(\mathrm{CaNO}_{3}\right)$ are promising in the control of $B$. cinerea. Several studies have evaluated the effect of calcium, both in flowers and fruits to control diseases (Volpin \& Elad, 1991; Conway et al., 1993). Since B. cinerea infects, preferably, tissues undergoing senescence (Jarvis, 1977), researchers have emphasized the utilization of calcium to increase the resistance of tissues and delay senescence, by inhibiting ethylene synthesis or action (Torre et al., 1999). This effect on ethylene production and mode of action culminates in the control of gray mold after the harvest of flowers (Elad \& Evensen, 1995)

Silver thiosulfate (STS) has been often used in the pulsing of flowers (Han, 1998). This substance improves the vase life of many species of flowers, by inhibiting the action of ethylene (Serek \& Reid, 1993). The STS increases the longevity and reduces abscission of flowers (Han, 1998). Many studies have utilized STS to increase flower vase life, but few have examined its ability to control $B$. cinerea in roses.

Considering the losses due to gray mold after harvest of roses and the potential of the afore mentioned substances in reducing these losses, a study was carried out to determine the effect of these substances on the vase life and gray mold severity in rose cv Kiss.

\section{MATERIALSANDMETHODS}

The experiments were conducted in the laboratories of the "Departamento de Fitopatologia" of the "Universidade Federal de Viçosa" and in commercial greenhouses and packinghouses in Barbacena, State of Minas Gerais, Brazil. Two experiments, repeated once, were conducted. In experiment I, rose flowers were pulsed with citric acid, salicylic acid, sucrose, and calcium sulfate, and in experiment II, rose flowers were pulsed with STS. The STS was evaluated separately from the other substances, because it may be toxic to flowers when they are exposed to it for too long, and because the other substances need more than $10 \mathrm{~h}$ to have an effect. In each experiment two assays were performed. In the first assay, we evaluated the effect of treatments on latent infections derived from the field and on infections occurring naturally after harvest. In the second assay, we evaluated the effect of treatments on flowers artificially inoculated with $B$. cinerea. In both experiments, inoculation was accomplished by using a DeVilbis atomizer and applying a volume of about $0.1 \mathrm{ml}$ of a spore suspension of $10^{4}$ conidia/ml to each flower. In the repetition of the experiments, the inoculated flowers were treated with double the volume of inoculum used the first time to determine if the efficiency of the treatments was altered with an increase in the amount of inoculum.

A scale of ratings showing the descriptions of the successive stages of floral opening was developed specifically to be used in the present work (Table 1).

A completely randomized experimental design with three replications of each treatment was used in all experiments.

\section{Pulsing with citric acid, salicylic acid, sucrose, and calcium sulfate}

Rose flowers of cv Kiss were harvested at three different stages: at the commercial harvest stage (stage I), which corresponds to a rating of 0 in Table $1 ; 24 \mathrm{~h}$ before stage I (stage II); and $48 \mathrm{~h}$ before stage I (stage III). A total of 900 flowers, 20 per replication of a total of three replications of each stage and substance, were placed into vases containing, separately, the solutions of citric acid at $0.8 \mathrm{mM}$, salicylic acid at $7.2 \mathrm{mM}$, sucrose at $2.4 \mathrm{mM}$, calcium sulfate at $50 \mathrm{mM}$, or water as controls. After pulsing for $15 \mathrm{~h}$, the flowers were divided in two groups of 450 flowers each. One group was inoculated, as previously described, and covered with plastic bags. The other group was not inoculated to evaluate the effect of the treatments on latent infections originated in the field or naturally after harvest. Both inoculated and uninoculated flowers were packed separately and stored at $10{ }^{\circ} \mathrm{C}$ and $\mathrm{RH}>90 \%$. After 36 to $48 \mathrm{~h}$, the flowers were placed in vases containing tap water, and both the vase life and the severity of disease were evaluated using the scale (Table 1), and a scale used by Araújo (1995), which varies from 1 to 10, where $1=0 \%$, $2=0-2 \%, 3=2-5 \%, 4=5-10 \%, 5=10-15 \%, 6=15-25 \%, 7=25-$ $50 \%, 8=50-75 \%, 9=75-100 \%$, and $10=100 \%$ of the diseased area in each petal, respectively.

Severity was considered the area of the petal that was diseased, relative to the total petal area. Before statistical analysis each severity rating was converted to a disease proportion, in which the midpoint of the interval was used

TABLE 1 - Scale of ratings showing the descriptions of the successive stages of floral opening

\begin{tabular}{cl}
\hline \hline Rating & \multicolumn{1}{c}{ STAGE OF FLORAL OPENING } \\
\hline $\mathbf{0}$ & $\begin{array}{l}\text { Floral stem showing green leaves totally hydrated, flower } \\
\text { with sepals vertically adhered to about } 2 / 3 \text { of its length to the } \\
\text { external petals, which are in the opening process } \\
\text { (Commercial harvest stage). }\end{array}$ \\
& $\begin{array}{l}\text { Floral stem showing green and well hydrated leaves, flower } \\
\text { with sepals beginning to fold down, and external petals a } \\
\text { little more opened. Intermediate petals starting to open. }\end{array}$ \\
& $\begin{array}{l}\text { Floral stem showing leaves still green and hydrated. Flower } \\
\text { with sepals almost totally bent. External petals completely } \\
\text { opened and starting curvature of the edges. Intermediate } \\
\text { petals well opened. }\end{array}$ \\
& $\begin{array}{l}\text { Green leaves and well hydrated. Flowers with scpals totally } \\
\text { curved down. External petals almost horizontal with the } \\
\text { edges mostly curved. Intermediate petals totally opened, and }\end{array}$ \\
& internal petals starting to open. \\
& $\begin{array}{l}\text { Leaves loosing turgidity. Sepals completely curved down, } \\
\text { and petals totally opened displaying the reproductive organs. }\end{array}$ \\
& Floral stem showing general lost of turgidity. At this stage the \\
& neck starts to bent. \\
& Floral stem totally dehydrated. Dead flower.
\end{tabular}


(Campbell \& Madden, 1990). The values of maximum severity and area under the disease progress curve (AUDPC) were compared among the treatments. The equation proposed by Shanner \& Finney (1977) was used to calculate AUDPC, where:

$$
\text { AUDPC }=\Sigma\left[\left(\mathrm{y}_{\mathrm{i}}+\mathrm{y}_{\mathrm{i}+1}\right) / 2 *\left(\mathrm{t}_{\mathrm{i}+1}-\mathrm{t}_{\mathrm{i}}\right)\right],
$$

in which $y_{i}$ is disease severity at time $t_{i}$, in days, and $y_{i+1}$ is disease severity at $t_{i+1}$.

Statistical analysis was done using ANOVA and Tukey's test $(P=0.05)$.

\section{Pulsing with silver thiosulfate (STS)}

A total of 240 flowers of the cv. Kiss were harvested in stage 0 of the scale of ratings (Table 1) and placed separately in 201 buckets half filled with tap water (four buckets with 60 flowers each). One group of 60 flowers was then transferred to a bucket containing 101 of a $1 \mathrm{mM}$ STS solution and let pulse for $120 \mathrm{~min}$. Sixty-min after the first group was transferred to the STS solution, another group of 60 flowers was transferred to a bucket with the same solution. Finally, $90 \mathrm{~min}$ after the first group was transferred, another group of 60 flowers was transferred to the STS solution. In this way the treatments were pulsing for $120 \mathrm{~min}, 60 \mathrm{~min}$, and $30 \mathrm{~min}$, respectively. The control flowers were transferred to a bucket containing water at the same time the first group of flowers was transferred to the STS solution.

At the end of the pulsing time ( $2 \mathrm{~h}$ total), the sixty flowers of each bucket were divided into three groups of 20 flowers each, which were considered as replications. Ten flowers of each replication group of each treatment were inoculated as described before. The other ten flowers were not inoculated to evaluate disease severity due to latent infections from the field or infections initiated after harvest. Once inoculated, the flowers were covered with plastic bags, packed separately from the non-inoculated ones, and stored at $10{ }^{\circ} \mathrm{C}$ and $\mathrm{RH}>90 \%$. After storing for 36 to $48 \mathrm{~h}$ the flowers were placed in vases, which were stored at $20^{\circ} \mathrm{C}$ and $\mathrm{RH}>80 \%$ under continuous light, and both the vase life and the severity of disease were evaluated as described. Analysis of variance and linear regression $(P$ $=0.05)$ were used for statistical analysis.

\section{RESULTS}

\section{Effect of the treatments on the progress of the disease}

In the assay without inoculation, there was a significant difference in the AUDPC between treatments for stages I (commercial harvest stage) and II ( $24 \mathrm{~h}$ after commercial harvest stage), but not for stage III ( $48 \mathrm{~h}$ after commercial harvest stage) (Table 2). For stage I, calcium sulfate was the most effective, reducing AUDPC by 59\%. The other treatments did not differ from the controls. For stage II, only calcium sulfate differed from the control, reducing the AUDPC by $61 \%$. However, calcium sulfate did not differ from the other substances. For stage III, no differences were found among treatments. In the repetition of the assay, at stage I, only calcium sulfate was different from the treatments and the controls, reducing AUDPC by $62 \%$. At stages II and III, only calcium sulfate differed from the controls, and reduced AUDPC by $66 \%$ and $56 \%$, respectively, but it did not differ from the other treatments.

In the assay with artificial inoculation, for stage I, there was no difference between treatments (Table 2). For stage II, the effects of salicylic acid, sucrose, and calcium sulfate generated a smaller AUDPC than the control. For stage III, all treatments but citric acid differed from the control. In the repetition of the assay, for stage I, pulsing with salicylic acid was the only treatment that differed from the controls. For stage II, no difference between pulsing with salicylic acid and calcium sulfate was observed, but they differed from the controls and the other treatments. For stage III, salicylic acid differed from the other treatments, including the control. Overall, for both assays, values of AUDPC did not differ among harvest stages.

\section{Effect of the treatments on maximum severity}

For this variable, statistical analysis was proceeded just for the assay without inoculation (Table 3). All flowers of the assay with inoculation were rated at the highest severity for the last evaluation. In the assay without inoculation, considering stage I, the effect of calcium sulfate was statistically different from the other treatments and the control. Sucrose was also different from the control. For stage II all treatments differed from the control, and pulsing with calcium sulfate was the most effective. For stage III, pulsing with calcium sulfate and sucrose reduced maximum severity by $72 \%$ and $50 \%$, respectively, which were different from the treatments with citric and salicylic acids. In the repetition of the assay, all treatments

TABLE 2 - Area under the disease progress curve of gray mold of rose (Rosa hybrida) after pulsing with solutions of citric acid (CA), salicylic acid (SA), sucrose (S), calcium sulfate (CS), and water controls (C) in the assays without inoculation (WI) and with inoculation (I) repeated once (1 and 2)

\begin{tabular}{|c|c|c|c|c|c|c|c|}
\hline \multicolumn{8}{|c|}{ TREATMENTS } \\
\hline \multicolumn{8}{|c|}{ WI } \\
\hline Rep. & Stage & CA & SA & $\mathbf{S}$ & $\mathrm{CS}$ & $\mathrm{C}$ & $\mathrm{CV}$ \\
\hline \multirow{3}{*}{1} & I & $2.97 \mathrm{~A}$ & $3.15 \mathrm{~A}$ & $2.06 \mathrm{AB}$ & $1.12 \mathrm{~B}$ & $2.74 \mathrm{~A}$ & \multirow{3}{*}{33.12} \\
\hline & II & $1.75 \mathrm{AB}$ & $1.97 \mathrm{AB}$ & $1.79 \mathrm{AB}$ & $1.07 \mathrm{~B}$ & $2.72 \mathrm{~A}$ & \\
\hline & III & $1.82 \mathrm{~A}$ & $2.07 \mathrm{~A}$ & $1.44 \mathrm{~A}$ & $1.22 \mathrm{~A}$ & $2.22 \mathrm{~A}$ & \\
\hline \multirow{3}{*}{2} & I & $1.71 \mathrm{~A}$ & $1.99 \mathrm{~A}$ & $1.66 \mathrm{~A}$ & $0.84 \mathrm{~B}$ & $2.23 \mathrm{~A}$ & \multirow{3}{*}{36.57} \\
\hline & II & $1.41 \mathrm{AB}$ & $1.83 \mathrm{AB}$ & $1.64 \mathrm{AB}$ & $0.94 \mathrm{~B}$ & $2.79 \mathrm{~A}$ & \\
\hline & III & $1.56 \mathrm{AB}$ & $1.85 \mathrm{AB}$ & $1.45 \mathrm{AB}$ & $1.20 \mathrm{~B}$ & $2.76 \mathrm{~A}$ & \\
\hline \multicolumn{8}{|c|}{ I } \\
\hline \multirow{3}{*}{1} & I & $6.13 \mathrm{~A}$ & $5.77 \mathrm{~A}$ & $5.68 \mathrm{~A}$ & $5.65 \mathrm{~A}$ & $6.13 \mathrm{~A}$ & \multirow{3}{*}{3.69} \\
\hline & II & $6.23 \mathrm{AB}$ & $6.06 \mathrm{~B}$ & $5.52 \mathrm{C}$ & $5.52 \mathrm{C}$ & $6.58 \mathrm{~A}$ & \\
\hline & III & $6.18 \mathrm{AB}$ & $5.91 \mathrm{BC}$ & $5.50 \mathrm{CD}$ & $5.36 \mathrm{D}$ & $6.49 \mathrm{~A}$ & \\
\hline \multirow{3}{*}{2} & I & $6.97 \mathrm{~A}$ & $5.55 \mathrm{~B}$ & $6.94 \mathrm{~A}$ & $6.36 \mathrm{~A}$ & $6.39 \mathrm{~A}$ & \multirow{3}{*}{5.09} \\
\hline & II & $6.94 \mathrm{~A}$ & $5.28 \mathrm{~B}$ & $6.86 \mathrm{~A}$ & $5.89 \mathrm{~B}$ & $6.60 \mathrm{~A}$ & \\
\hline & III & $6.93 \mathrm{~A}$ & $4.66 \mathrm{~B}$ & $7.02 \mathrm{~A}$ & $6.31 \mathrm{~A}$ & $6.40 \mathrm{~A}$ & \\
\hline
\end{tabular}

Values represent the means of three replications. Values followed by the same letter, in the same line (treatment inside each stage), are not statistically different by Tukey's test $(P=0.05)$. CV $=$ coefficient of variation. 
Gray mold severity and vase life of rose buds after...

differed from the controls for the three stages. Again, calcium sulfate was the most effective reducing maximum severity by $78 \%, 78 \%$, and $69 \%$ for stages I, II, and III, respectively.

\section{Effect of the treatments on vase life}

In the assay without inoculation, all substances but salicylic acid increased the vase life of the flowers (Table 4). For all three stages, pulsing with calcium sulfate was the most effective. In the repetition of the assay, calcium sulfate was again the most effective and increased the flowers vase life by $32 \%$ for stage III. Overall, in the assay with inoculation, only treatment with calcium sulfate increased the vase life of the flowers.

\section{Effect of STS on the variables studied}

In the assay without inoculation the values of AUDPC were not affected by the pulsing times to which the flowers were exposed to STS. However, for the assay with inoculation, differences were detected between pulsing times, where a quadratic tendency in reducing AUDPC was observed (Figure 1).

In considering maximum severity, differences were detected between pulsing times only in the assay without inoculation. A very similar quadratic tendency to reduction of maximum severity values was found both times the assay was conducted (Figure 2). In the assay with inoculation, all flowers received the maximum score for severity.

Treatment with STS increased the vase life of the flowers both times the assay with inoculation was conducted. Here, as the two very similar quadratic curves show, the vase life increased as pulsing time increased (Figure 3A). In the assay with inoculation, vase life increased with increased pulsing time only the first time the experiment was conducted (Figure $3 \mathrm{~B})$. In the repetition of the assay no differences were found among treatments.

\section{DISCUSSION}

Pulsing with calcium sulfate was the most effective in reducing disease and, in the assays without inoculation, it

TABLE 3 - Maximum severity of gray mold of rose (Rosa hybrida) dafter pulsing with solutions of citric acid (CA), salicylic acid (SA), sucrose (S), calcium sulfate (CS), and water controls in the assay without inoculation (WI) repeated once (1 and 2)

\begin{tabular}{lccccccc}
\hline \hline \multicolumn{7}{c}{ TREATMENTS } \\
\multicolumn{7}{c}{ WI } \\
\hline Rep & Stage & \multicolumn{1}{c}{ CA } & \multicolumn{1}{c}{ SA } & S & CS & C & CV \\
\hline & I & $0.74 \mathrm{AB}$ & $0.66 \mathrm{AB}$ & $0.56 \mathrm{~B}$ & $0.28 \mathrm{C}$ & $0.93 \mathrm{~A}$ & \\
$\mathbf{1}$ & II & $0.53 \mathrm{BC}$ & $0.54 \mathrm{BC}$ & $0.58 \mathrm{~B}$ & $0.27 \mathrm{C}$ & $0.94 \mathrm{~A}$ & 20.82 \\
& III & $0.56 \mathrm{~B}$ & $0.57 \mathrm{~B}$ & $0.47 \mathrm{BC}$ & $0.26 \mathrm{C}$ & $0.93 \mathrm{~A}$ & \\
\hline & I & $0.49 \mathrm{~B}$ & $0.48 \mathrm{~B}$ & $0.47 \mathrm{~B}$ & $0.20 \mathrm{C}$ & $0.92 \mathrm{~A}$ & \\
$\mathbf{2}$ & II & $0.43 \mathrm{~B}$ & $0.48 \mathrm{~B}$ & $0.43 \mathrm{~B}$ & $0.21 \mathrm{C}$ & $0.95 \mathrm{~A}$ & 30.95 \\
& III & $0.47 \mathrm{~B}$ & $0.47 \mathrm{~B}$ & $0.40 \mathrm{~B}$ & $0.29 \mathrm{~B}$ & $0.92 \mathrm{~A}$ & \\
\hline
\end{tabular}

Percentage values represent means of three replications. Values followed by the same letter, in the same line (treatment inside each stage) are not statistically different by Tukey's test $(P=0.05) . \mathrm{CV}=$ coefficient of variation.
TABLE 4 - Vase life of the rose (Rosa hybrida) flowers after pulsing with solutions of citric acid (CA), salicylic acid (SA), sucrose (S), calcium sulfate (CS), and water controls (C) in the assays without inoculation (WI), and with inoculation (I) repeated once (1 and 2)

\begin{tabular}{lccccccc}
\hline \hline \multicolumn{7}{c}{ TREATMENTS } \\
\multicolumn{7}{c}{ WI } \\
\hline Rep & Stage & CA & SA & S & CS & C & CV \\
\hline $\mathbf{1}$ & I & $8.5 \mathrm{~A}$ & $7.1 \mathrm{C}$ & $8.1 \mathrm{~B}$ & $9.1 \mathrm{~A}$ & $7.1 \mathrm{C}$ & \\
& II & $8.2 \mathrm{~B}$ & $7.4 \mathrm{BC}$ & $7.7 \mathrm{~B}$ & $9.3 \mathrm{~A}$ & $6.8 \mathrm{C}$ & 4.69 \\
& III & $8.0 \mathrm{~B}$ & $6.9 \mathrm{C}$ & $8.4 \mathrm{~B}$ & $9.3 \mathrm{~A}$ & $6.9 \mathrm{C}$ & \\
\hline $\mathbf{2}$ & I & $7.9 \mathrm{~B}$ & $7.2 \mathrm{~B}$ & $7.7 \mathrm{~B}$ & $9.3 \mathrm{~A}$ & $7.1 \mathrm{~B}$ & \\
& II & $8.0 \mathrm{BC}$ & $7.1 \mathrm{C}$ & $8.2 \mathrm{~B}$ & $9.5 \mathrm{~A}$ & $7.6 \mathrm{BC}$ & 5.32 \\
& III & $7.9 \mathrm{BC}$ & $7.0 \mathrm{C}$ & $8.2 \mathrm{~B}$ & $9.5 \mathrm{~A}$ & $7.2 \mathrm{BC}$ & \\
\hline & & & & I & & & \\
\hline $\mathbf{1}$ & I & $6.4 \mathrm{~B}$ & $7.2 \mathrm{~A}$ & $7.1 \mathrm{AB}$ & $7.7 \mathrm{~A}$ & $6.4 \mathrm{~B}$ & \\
& II & $6.4 \mathrm{~B}$ & $7.1 \mathrm{AB}$ & $7.0 \mathrm{~B}$ & $7.7 \mathrm{~A}$ & $6.7 \mathrm{~B}$ & 4.34 \\
& III & $6.7 \mathrm{BC}$ & $7.3 \mathrm{~B}$ & $7.3 \mathrm{~B}$ & $8.0 \mathrm{~A}$ & $6.5 \mathrm{C}$ & \\
\hline $\mathbf{2}$ & I & $6.0 \mathrm{~B}$ & $6.0 \mathrm{~B}$ & $6.5 \mathrm{AB}$ & $7.0 \mathrm{~A}$ & $5.9 \mathrm{~B}$ & \\
& II & $6.3 \mathrm{ABC}$ & $6.1 \mathrm{BC}$ & $6.4 \mathrm{AB}$ & $6.7 \mathrm{~A}$ & $5.7 \mathrm{C}$ & 4.23 \\
& III & $6.0 \mathrm{~B}$ & $6.2 \mathrm{~B}$ & $6.3 \mathrm{~B}$ & $7.1 \mathrm{~A}$ & $6.0 \mathrm{~B}$ & \\
\hline
\end{tabular}

Values represent the means of days of three replications. Values followed by the same upper case letter, in the same line (treatment inside each stage) are not statistically different by Tukey's test $(P=0.05) . \mathrm{CV}=$ coefficient of variation.

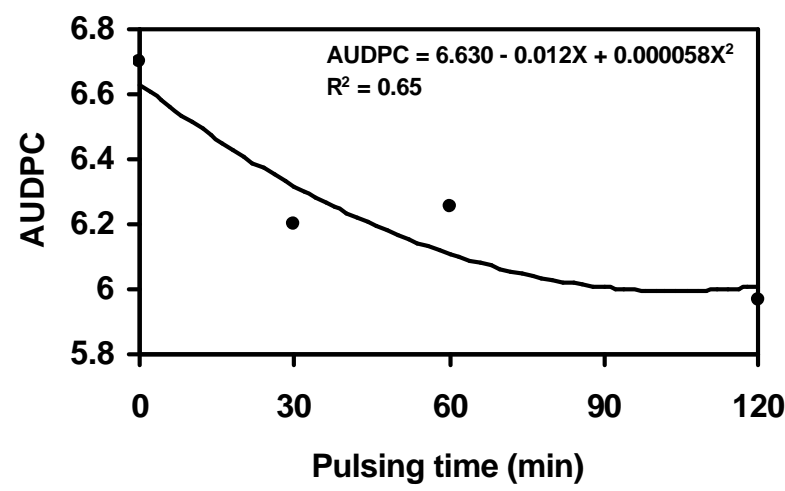

FIG. 1 - Area Under the Disease Progress Curve (AUDPC) of gray mold of rose (Rosa hybrida) as a function of the pulsing time (T), in minutes, in a $1 \mathrm{mM}$ silver thiosulfate solution. First repetition of the assay with inoculation.

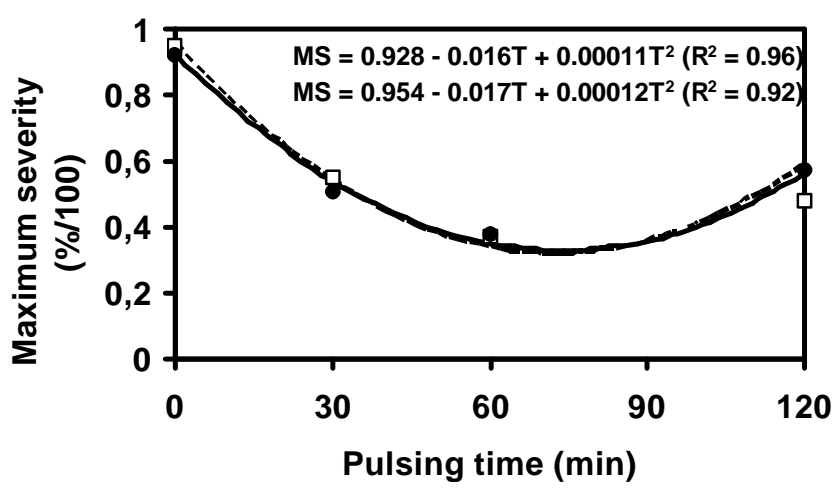

FIG.2 - Maximum Severity (MS) of gray mold on rose (Rosa hybrida) as a function of the pulsing time (T), in minutes, in a $1 \mathrm{mM}$ silver

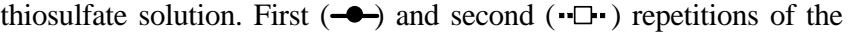
assay without inoculation. 
significantly reduced AUDPC by $66 \%$ and maximum severity by $78 \%$, and increased vase life of the flowers by $37 \%$. The effects of calcium sulfate may be explained by considering that calcium ions increase cell wall resistance to degradation caused by the complex of polygalacturonases, and other enzymes involved in the process of pathogenesis of $B$. cinerea (Elad \& Evensen, 1995). As the resistance of cellular structures against the enzymes was increased, the number of successful infections as well as the progress of disease was probably reduced.

One of the main responses of carnation (Dianthus caryophyllus L.) petals to exposure to ethylene is ion leakage due to alteration in the membrane integrity (Bo et al., 1997). This is probably true with rose petals as well. The calcium ion seems to inhibit ethylene production by maintaining plasmamembrane integrity (Nur et al., 1986). Consequently, there is a reduction in membrane permeability that leads to a reduction in electrolyte loss to the apoplast, which may affect conidium germination and penetration by the pathogen (Elad \& Evensen, 1995). Roses grown on a high calcium concentration produced less ethylene, and had a higher resistance to $B$. cinerea than untreated ones (Volpin \& Elad, 1991). These authors also pointed out the existence of marked differences among rose varieties in the response to treatment with calcium sulfate.

The other treatments did not reduce disease markedly, except in a few situations. Although in most situations AUDPC and maximum severity in the salicylic acid treatment did not differ from the treatments with sucrose and citric acid, the vase
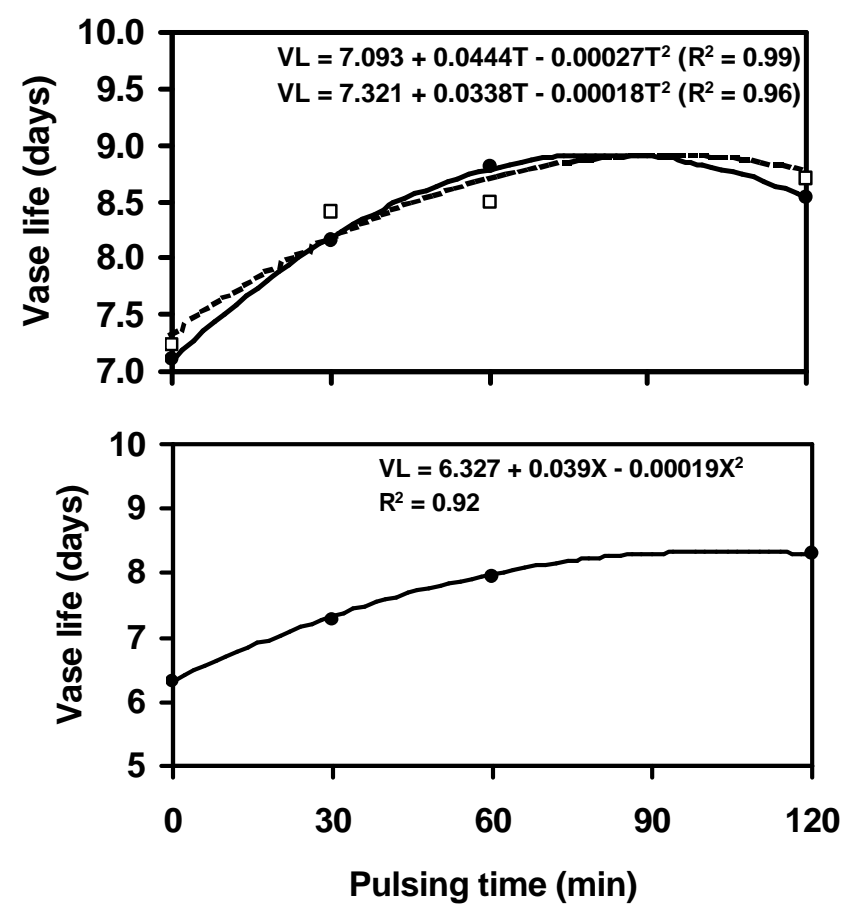

FIG. 3 - Vase Life (VL) of rose (Rosa hybrida) as a function of the pulsing time (T), in minutes, in a $1 \mathrm{mM}$ silver thiosulfate solution. A $=$ first $(-\infty)$ and second (.. $\square$. ) repetitions of the assay without inoculation. $\mathrm{B}=$ first repetition of the assay with inoculation. life of the flowers treated with this acid was considerably reduced. Probably the pulsing time with salicylic acid at 7.2 $\mathrm{mM}$ used in this work was too long. This combination may have injured xylem vessels and collapsed the water flux up to the petals, culminating with flower dehydration. This dehydration may have reduced both the vase life of the flowers and advancement of the disease due to lack of moisture in the invaded tissues. Despite the failure of treatment with salicylic acid in this study, some authors have shown its ability to induce resistance in plants (De et al., 1999), in addition to its direct effect on the pathogen (Gaur \& Chenulu, 1982) and its effect on ethylene synthesis. Salicylic acid has been shown to have an inhibitory action toward auxin-induced ethylene biosynthesis when tested on mung bean (Vigna radiata $\mathrm{L}$. Wilzeck) (Lee et al., 1999). Therefore, it is important to test different pulsing times with lower concentrations of this acid to evaluate its ability to control gray mold of roses.

The effects of sucrose and citric acid on the AUDPC, maximum severity, and vase life of the flowers were not statistically different for most of the situations. Apparently, sucrose provides energy for fundamental cellular processes, such as the maintenance of the structure and functions of mitochondria. It also regulates water balance by controlling transpiration (Nowak \& Rudinicki, 1990). The latter authors emphasized the importance of knowing the concentrations tolerated by each species or even variety of flower. For example, roses, carnations, and gladiolus (Gladiolus liliaceus Houtt.) have different sugar concentration requirements in pulsing to extend their vase life (Halevy \& Mayak, 1974). Citric acid is considered to maintain the water balance and to reduce bacterial proliferation in the vase solution, thus avoiding the obstruction of the xylem vessels. When combined with other substance, citric acid gave the best results in terms of longevity in bird-ofparadise (Strelitzia reginae Banks.) flowers compared to other combinations (Halevy et al., 1978b). It is possible that combining sucrose with citric acid or other substances may produce additive or synergistic effects, either by increasing the vase life or by reducing disease severity.

In the assay with inoculation, pulsing with calcium sulfate was the most efficient in reducing the AUDPC and in increasing vase life. However, in the repetition of the experiment, in which the volume of inoculum was doubled, there was a considerable reduction in the effect of the treatments. Here, the efficacy of calcium sulfate as well as of sucrose and citric acid was considerably reduced, probably because more inoculum available means more enzymes being produced to macerate the infected tissue.

In the experiment withSTS the treatments affected the progress of disease only the first time the assay with inoculation was conducted, but not in the repetition of the experiment. Reduction of the maximum severity was found in the assay without inoculation. Most studies using STS have been directed at improving the postharvest quality of many flowers without considering its effect on pathogens (Serek et al., 1994). The STS reduced the severity of gray mold on rose and carnation by inhibiting the ethylene action (Elad, 1988). 
Gray mold severity and vase life of rose buds after...

This inhibition reduced the senescence of the flowers, and consequently, the advance in pathogen colonization. The effect of STS on senescence is due to the action of the silver ion (Knee, 1992). This ion binds to specific sites in the cell membrane competitively blocking the ethylene action on it, culminating in a reduction of senescence. All treatments studied increased the vase life of the roses. These findings are similar to previous results (Serek et al., 1994; Han, 1998). Although STS has been shown to have good effect on reducing flower senescence, one should be aware that silver is a heavy metal, and, because of that, it has the potential to damage the environment and human health.

According to our study, treating rose buds with substances that reduce the rate of senescence of flowers is efficient to increase the vase life and to reduce the damage by pathogens such as $B$. cinerea that colonize senescent tissues. The most effective substances tested were calcium sulfate followed by sucrose and STS in that order. The other substances did not have a significant effect. Nevertheless, it will be necessary to combine the use of these substances with preharvest treatments to find additive or synergistic effects for satisfactory disease control.

\section{ACKNOWLEDGEMENTS}

We thank Dr. James R. Aist from the Department of Plant Pathology at Cornell University for critically reviewing this manuscript. We also thank the Brazil Flowers SA and its agronomist Mr. Joao Miranda for providing basic support and field facilities for the conduct of this work. Finally, we thank the Fundação de Amparo a Pesquisa de Minas Gerais (FAPEMIG) for financing this research work, and the Coordenadoria de Aperfeiçoamento de Pessoal de Nível Superior (CAPES) of the Brazilian Education Ministry for supporting the first author with a scholarship during completion of his Master's Degree in Plant Pathology.

\section{LITERATURE CITED}

ARAUJO, A.E. Sobrevivência de Botrytis cinerea em restos de cultura, efeito de fatores do ambiente sobre o patógeno e progresso do mofo cinzento em roseiras cultivadas em casas de vegetação. (MSc. Dissertation). Viçosa. Universidade Federal de Viçosa. 1995.

BO, J.W., MAYAK, S. \& HALEVY, A.H. Responses to ethylene and protein synthesis of carnation flowers. Acta Botanica Sinica 39: 991997. 1997.

CAMPBELL, C.L. \& MADDEN, L.V. Introduction to plant disease epidemiology. John Wiley \& Sons Inc., New York. 1990.

CONWAY, W.S., SAMS, C.E., \& TOBIAS, R.B. Reduction of storage decay in apples by postharvest calcium infiltration. Acta Horticulturae 326:115-121. 1993.

DE, M.G., CAPIEAU, K., AUDENAERT, K., BUCHALA, A., METRAUX, J.P., \& HOFTE, M. Nanogram amounts of salicylic acid produced by the rhizobacterium Pseudomona auriginosa 7NSK2 activate the Systemic Acquired Resistance pathway in bean. Molecular
Plant-Microbe Interaction 12:450-458. 1999.

ELAD, Y. Involvement of ethylene in the pathogenicity of Botrytis cinerea on rose and carnation flowers and the possibility of control. Annals of Applied Biology 113:589-598. 1988.

ELAD, Y. \& EVENSEN, K. Physiological aspects of resistance to Botrytis cinerea. Phytopathology 85:637-643. 1995.

GAUR, A. \& CHENULU, V.V. Chemical control of postharvest disease of Citrus reticulata and Solanum tuberosum. Indian Phytopathology 35:623-632. 1982.

HALEVY, A.H. \& MAYAK, S. Improvement of cut flower quality opening and longevity by pre-shipment treatments. Acta Horticulturae 43:335-347. 1974.

HALEVY, A.H., BYRNE, T.G., KOFRANEK, A.M., FARNHAM, D.S. \& THOMPSON, J.F. Evaluation of postharvest handling methods for transcontinental truck shipments of cut carnation, chrysantemus and roses. Journal of the American Society for Horticultural Science 103:165-169. 1978a.

HALEVY, A.H., KOFRANEK, A.M. \& BESEMER, S.T. Postharvest handling methods of Bird-of-Paradise flowers (Strelitzia reginae Ait.). Journal of the American Society for Horticultural Science 103:165169. 1978 b.

HAN, S.S. Postharvest handling of cut Heuchera sanguinea Engelm. Flowers:Effect of sucrose and silver thiosulfate. Hortiscience 33:731733. 1998.

JARVIS, W.R. Botryotinia and Botrytis Species:taxonomy, physiology and pathogenicity. Canada Department of Agriculture, Ontario. 1977.

KNEE, M. Sensitivity of ATPases to silver ions suggests that silver acts outside the plasma membrane to block ethylene action. Phytochemistry 31:1093-1096. 1992.

LEE, J.H., JIN, E.S. \& KIM, W.T. Inhibition of auxin-induced ethylene production by salicylic acid in mung bean hypocotyls. Journal of Plant Biology 42:1-7. 1999.

NOWAK, J. \& RUDNICKI, R.M. Postharvest handling and storage of cut flowers, florist greens and potted plants. Timber Press, Portland. 1990.

NUR, T., BEN, A.R., LURIE, S. \& ALTMAN, A. Involvement of divalent cations in maintaining cell membrane integrity in stressed apple fruit tissues. Journal of Plant Physiology 125:47-60. 1986.

RYALS, J.A., NEUENSCHWANDER, U.H., WILLITS, M.G., MOLINA, A., STAINER, H.Y. \& HUNT, M.D. Systemic acquired resistance. Plant Cell 8:1808-1819. 1996.

SEREK, M., JONES, R.B. \& REID, M.S. Role of ethylene in opening and senescence of Gladiolus sp. flowers. Journal of the American Society for Horticultural Science 119:1014-1019. 1994.

SEREK, M. \& REID, M.S. Anti-ethylene treatments for potted Christmas cactus - Efficacy of inhibitors or ethylene action and biosynthesis. HortScience 28:1180-1181. 1993.

SHANNER, G. \& FINNEY, R.E. The effect of nitrogen fertilization on the expression of slow-mildewing resistance in Knox wheat. Phytophatology 70:1183-1186. 1977.

TORRE, S., BOROCHOV, A. \& HALEVY, A.H. Calcium regulation of senescence in roses. Physiologia Plantarum 107:214-219. 1999.

VOLPIN, H. \& ELAD, Y. Influence of calcium nutrition on susceptibility of rose flowers to Botrytis blight. Phytopathology 81:1390-1394. 1991. 